\section{A Marchadeira das famílias bem pensantes: a pintura de Flávio Império entre o máximo e o neutro teatral}

A Marchadeira das famillias bem pensantes: Flávio Império's painting between the maximum theatrical and the neutral theatrical

Yuri Fomin Quevedo*

*Professor de História da Arte na Escola da Cidade. Possui mestrado pela Faculdade de Arquitetura e Urbanismo da USP (2019). Graduou-se em Arquitetura e Urbanismo pela Escola da Cidade (2014). Atua como professor, pesquisador, curador de exposições e livros, yurifquevedo@gmail.com

\begin{tabular}{|c|c|c|}
\hline Palavras-chave: & Resumo & Abstract \\
\hline Flávio Império. & Este artigo parte da pintura A Marchadeira das famílias bem pensantes, & This article starts from the painting A Marchadeira das familias bem \\
\hline Pintura. & realizada por Flávio Império em 1965, para perscrutar a maneira com & pensantes, done by Flávio Império in 1965 , to examine how the artist \\
\hline Ditadura Militar. & $\begin{array}{l}\text { que o artista elabora a crítica à ditadura militar por meio de seu traba- } \\
\text { Iho. Para isso, retoma brevemente o termo Pintura Nova, e seus signifi- }\end{array}$ & $\begin{array}{l}\text { criticizes the military dictatorship through his work. For this, it briefly re- } \\
\text { turns to the term Pintura Nova, and its meanings within the partnership }\end{array}$ \\
\hline Keywords: & cados dentro da parceria com Sérgio Ferro e Rodrigo Lefévre, como & with Sérgio Ferro and Rodrigo Lefévre, as an instrument of knowledge \\
\hline Flávio Império. & seus elementos. Depois, levanta os comentários de Flávio Motta e Má- & $\begin{array}{l}\text { of reality, molded from its elements. Then, it ralses the comments of } \\
\text { Flávio Motta and Mário Schemberg at the critical reception of the artist's }\end{array}$ \\
\hline Painting. & rio Schemberg na recepção crítica da obra do artista. E, por fim, a partir & work. And, finally, based on texts by Flávio Império himself about his \\
\hline Dictatorship. & $\begin{array}{l}\text { de textos do próprio Flávio Império sobre sua atividade de cenógrafo, } \\
\text { aproxima a pintura das noções de sistema móvel, neutro e máximo tea- } \\
\text { tral, influenciadas pela leitura que Anatol Rosenfeld faz de Bertold Bre- } \\
\text { cht. O objetivo é aproximar as reflexões do artista à época entendendo } \\
\text { sua pintura também como uma forma de elaboração dessas questões, } \\
\text { tal como a arquitetura e a cenografia. }\end{array}$ & $\begin{array}{l}\text { activity as a scenographer, he brings painting closer to the notions of a } \\
\text { mobile, neutral and theatrical maximum system, influenced by Anatol } \\
\text { Rosenfeld's reading of Bertold Brecht. The objective is to bring the } \\
\text { artist's reflections to the time by understanding his painting to elaborate } \\
\text { on these issues, such as architecture and scenography. }\end{array}$ \\
\hline
\end{tabular}

usjt

\section{arq.urb}

número 29 | set-dez de 2020 Recebido: 10/03/2020 Aceito: $02 / 07 / 2020$ https://doi.org/10.37916/arq.urb.vi29.478

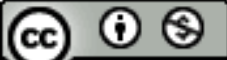




\section{A Marchadeira das famílias bem pensantes: a pintura de Flávio Império entre o máximo e o neutro teatral}

A Marchadeira das famílias bem pensantes, ${ }^{1}$ realizada em 1965 por Flávio Império, e hoje conservada na Pinacoteca do Estado de São Paulo, é uma pintura em madeira sobre a qual foram aplicados vários pequenos objetos. Trata-se do perfil caricato de uma mulher idosa. Seu rosto é feito com grafite, sem massa, apenas o contorno riscado por linhas finas que exageram feições sobre o fundo branco.

As vestes, casaco e chapéu, também são sugestões feitas por áreas de tinta preta sobre as quais é possível entrever letras translúcidas de uma página de jornal. As letras não têm cor, nem pigmento em sua composição. São vestígios deixados por um decalque possivelmente produzido a partir de uma página de jornal e cola. $\mathrm{O}$ jornal é usado novamente na composição do fundo recoberto pela tinta branca. Essa camada branca, que recalca a madeira, possui a textura do pigmento e ao mesmo tempo mantém uma transparência característica; própria de superfícies caiadas.

Sobre a pintura são juntadas várias peças e objetos industrializados. Aplicados no chapéu da mulher, soldadinhos de chumbo formam uma marcha. A montagem desses brinquedos alude àquele momento fecundo, idealmente épico, próprio da pintura de episódios históricos do século XIX. O conjunto parece um relevo em metal. A marcha de brinquedo, orienta todo o plano do quadro, inclusive o perfil da mulher - que é bem menos substancioso do que aquilo que a adorna.

Abaixo dela, engrenagens formam os cabelos, sugerindo cachos mecânicos, caraminholas; a maquinação que ocupa a cabeça da Marchadeira. Um puxador de gaveta, armário ou janela é aplicado na base da curva que indica sua orelha. Trata-se de um adorno, fundido em ferro, mas sem nenhuma característica específica ou marcante. Certamente produto de uma serialização industrial que usa a imagem do ornamento como estilo desconectado de seu contexto histórico.

Unidos, esses fragmentos, e integrados às demais partes do quadro, são atributos que montam a Marchadeira. Uma personagem tipo, expressão do conservadorismo, que alude à Marcha da Família com Deus pela Liberdade, passeata que acon-

'Este artigo é um desenvolvimento do primeiro capítulo da minha dissertação de mestrado , orientada pela Profa. Dra. Ana Maria Belluzzo, ver Quevedo, 2019. teceu em março de 1964 e foi vista como representação da sociedade civil em apoio a uma ruptura da democracia no Brasil. ${ }^{2}$

O quadro integra o conjunto de 25 trabalhos de Flávio Império, realizados entre 1964-1966, no período imediatamente após o Golpe Civil-Militar. Muitos deles hoje estão desaparecidos e se conhecemos sua existência é devido à documentação fotográfica. ${ }^{3}$ São relevos em gesso e pinturas com aplicações de pequenos objetos que reagem ao contexto político e social do país; formulando esta crítica em relação ao subdesenvolvimento econômico e à submissão aos Estados Unidos por meio de uma linguagem que investiga os procedimentos da Pop Art.

Esse conjunto foi mostrado diversas vezes ao longo da década de 1960, período em que $o$ artista se profissionaliza e realiza uma quantidade grande de exposições, dentre elas algumas das mais importantes para a história da arte no Brasil, as coletivas Opinião 65 (MAM-RJ) e Propostas 65 (FAAP). A Marchadeira esteve em ambas, a etiqueta no verso prova a primeira exibição, e a lista de obras do catálogo da mostra acusa a segunda. Na Galeria do Teatro de Arena, realiza uma individual em 1966, e é provavelmente quando escreve o texto A Pintura Nova tem a cara do cotidiano, ${ }^{4}$ dando essa denominação aquilo que fazia. $O$ termo é compartilhado pelo também pintor Sérgio Ferro. ${ }^{5}$

Neste artigo, pretendo olhar para $A$ Marchadeira das famílias bem pensantes, que é parte conjunto referido acima, e perscrutar os sentidos da crítica que Flávio Império formula por meio de seu fazer na pintura. Para isso, primeiro é preciso recuperar como o artista define a Pintura Nova. Depois, passaremos pela recepção dessas pinturas em comentários dos críticos Flávio Motta e Mário Schemberg. Por último, veremos o quadro em relação à noções do próprio Império: sistema móvel, neutro e máximo teatral. $\mathrm{O}$ objetivo é aproximar o quadro da ideia de experimentos

2Para uma visão detalhada da Marcha da Família com Deus pela Liberdade ver Sestini, 2008.

${ }^{3}$ São duas coleções de fotografias: a primeira provavelmente de 1967 por Benedito Lima de Toledo. A segunda foi realizada Sociedade Cultural Flávio Império (SCFI) que empreendeu a catalogação do acervo do artista, entre 1994-2000. Ambas fazem parte do acervo do Instituto de Estudos Brasileiros da Universidade de São Paulo (IEB-USP).

${ }^{4}$ Império, c.1966. O texto não foi publicado e não está datado. O papel timbrado e tom de manifesto do texto, corroboram a hipótese que seu objetivo era apresentar os trabalhos naquela ocasião.

${ }^{5} \mathrm{cf}$. uso do termo no texto do autor intitulado Os limites da denúncia, Ferro, 1967, p.3. 
sociológicos, como Anatol Rosenfeld 6 interpreta o trabalho de Bertold Brecht. Quero, dessa maneira, aproximar o trabalho do pintor daquele ele mesmo realizava enquanto cenógrafo, contribuindo para uma visão mais completa de sua atividade.

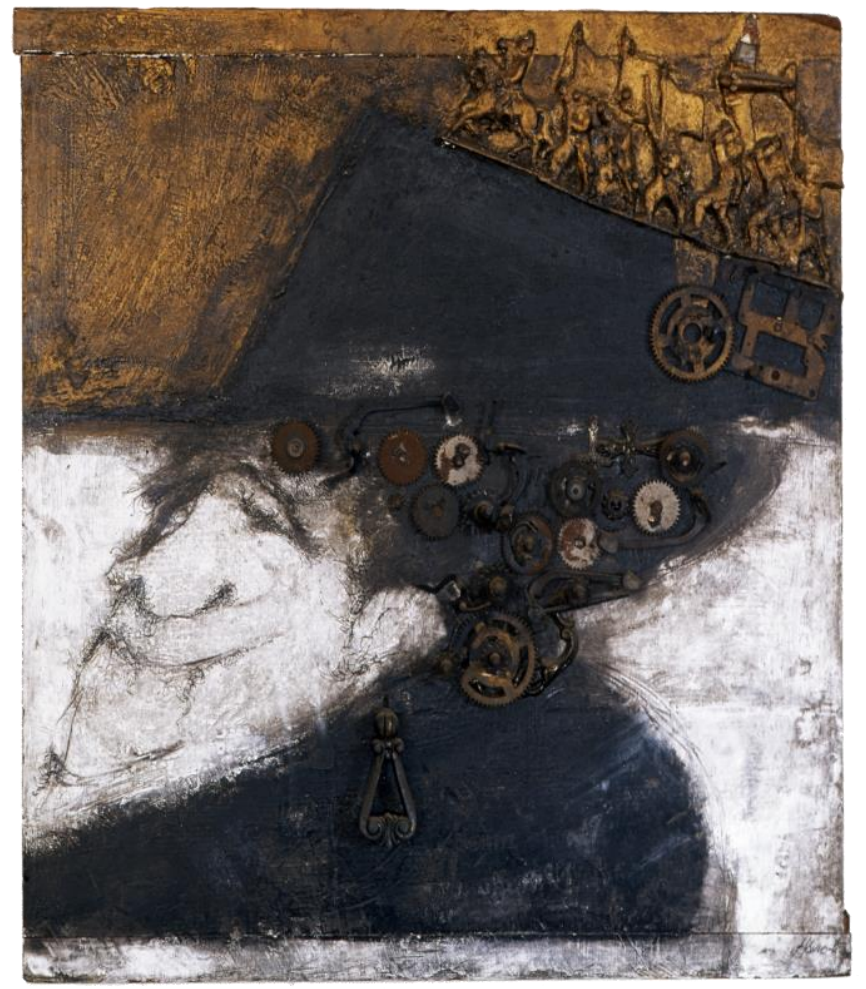

Figura 1: Flávio Império. A Marchadeira das famílias bem pensantes, 1965. Acrílica, grafite e colagem de papel e objetos sobre tela. 40 × $39 \mathrm{~cm}$. Acervo da Pinacoteca do Estado de São Paulo - Doação de Carlos Lemos, 2009

\section{A Pintura Nova tem a cara do cotidiano}

A Marchadeira e o termo Pintura nova brasileira estão ligados ao escritório de arquitetura que Flávio Império formou junto com Rodrigo Lefévre e Sérgio Ferro,

${ }^{6} \mathrm{~A}$ escolha deste autor não é aleatória, Flávio Império e ele eram colegas como professores da Escola de Arte Dramática (EAD) entre 1962-1966. O livro, O Teatro Épico tem sua primeira edição em 1965. amigos e parceiros fundamentais desde a faculdade que cursaram juntos. ${ }^{7}$ Após a graduação, os três imediatamente são contratados como assistentes de ensino na mesma escola, a FAUUSP. Além de suas atividades letivas e no escritório, Império é cenógrafo dos principais grupos de teatro da cidade - o Teatro de Arena e o Teatro Oficina - e artista plástico. Todos esses trabalhos são realizados no espaço em que convive com os outros dois companheiros e, muitas vezes, selam relações entre eles que vão para além da arquitetura. Lefévre assina com o artista a montagem de Todo Anjo é Terrível, em 1963, e também a reforma do Teatro Oficina em 1967. Com Sérgio Ferro, Império partilha o fazer da pintura - prática que ambos vão desenvolver de maneira muito próxima durante a década de 1960.

O estatuto dessas outras atividades artísticas desenvolvidas no âmbito do escritório de arquitetura pode ser aferido por meio do texto de Rodrigo Lefévre, publicado na revista Acrópole, de 1965.

"Para combater a marginalização mais diretamente, [o arquiteto] é forçado a penetrar em setores não ligados à construção, como a comunicação visual, o desenho industrial, etc.; é aumentada a atuação, pretensiosa em alguns casos, em campos próximos como a pintura, teatro, cinema, literatura, etc.; é incrementado o interesse pelo levantamento e interpretação dos fatos de nossa cultura e sentida a necessidade de maior difusão e discussão de nossa arquitetura, através de publicações, debates, conferências, exposições, etc.; numa tentativa de substituir a falha quase total de atuação pelo rigor de cada atitude.

Essa dispersão pode assumir características comprometidas com as condições do regime, subdesenvolvimento e subserviência é a escolha mais fácil e que tende a ampliar o conceito de arquitetura como artigo de luxo. Mas, ao contrário, essa dispersão, se consciente, controlada e ordenada, servindo para aumentar o conhecimento da nossa realidade, aliada a procura de interpretações coerentes, ajuda a estabelecer as bases para superação dessa situação"8

Nas palavras de Lefévre podemos entrever uma hierarquia na qual a arquitetura tem primazia. Podemos explicar isso pelo fato do texto ser dedicado a ela e não a outras atividades, que são vistas como dispersão arriscada, pois reiterariam elitis-

${ }^{7}$ Sobre o grupo, e a importância fundamental que tem para a História da Arquitetura, ver Koury, 2003. O termo Pintura Nova guarda relação com o termo Arquitetura Nova que consta do texto de Ferro de 1967. Cf. Ferro, 2006, pp. 47-58.

${ }^{8} \mathrm{O}$ trecho faz parte da reunião de textos escritos pelos três arquitetos intitulada Notas sobre Arquitetura e publicada originalmente no número 319 da revista Acrópole. A transcrição completa foi republicada sob o novo título Arquitetura Experimental em Ferro, 2006, pp. 37-39. 
mo da profissão. Por outro lado, essa mesma dispersão - no bojo da qual podemos incluir a Pintura Nova brasileira realizada por Império e Ferro -, se executada de forma consciente e rigorosa, serviria como ferramenta para o conhecimento e interpretação da realidade, estabelecendo bases para a superação do regime de subdesenvolvimento e subserviência.

Em que termos a Pintura nova brasileira constitui uma ferramenta de conhecimento? Justamente em seu esforço de engendrar a crítica social, política e econômica. Nesses trabalhos, são elaboradas imagens que organizam o cotidiano violento do Brasil pós-golpe como parte de um sistema de forças próprio do capitalismo, reconhecendo o país em sua posição na lógica internacional: subdesenvolvido e dominado. Em Os limites da denúncia, Sérgio Ferro fala sobre esse ponto:

"A pintura nova brasileira é manifestação clara do que hoje somos: colônia ianque. Expõe o complexo de atitudes contraditórias - atração e repulsão, denúncia e inveja, confusão que compõe as relações tensas entre o colonizador, seus representantes internos e o colonizado."

Os artistas operam essa crítica se apropriando da linguagem da Pop Art - que também denominam Pintura Nova - para falar dessas relações tensas. A linguagem, identificada como produto estadunidense, é usada também para aludir ao opressor, como iconografia característica, apresentando-o como parte do jogo de forças que organiza os quadros. Nesses trabalhos a Pop não é apenas um conjunto de técnicas, mas também uma espécie de leitmotiv, que introduz os Estados Unidos, o sistema capitalista de produção e a comunicação de massas, ao servir também como referência à eles. Segundo Flávio Império em A pintura nova tem a cara do cotidiano:

"A pintura nova brasileira é filha da 'pop', mas sem dúvida a ovelha-negra. Usa sua linguagem e reponde aos murros e pés-do-ouvido, mostrando o reverso da moeda. Como aprendiz de feiticeiro aprende a linguagem da publicidade e mostra que o rei está nu - como são valentes os 'general sin general', 'motors eletric', 'and so on'.

U.S.A. ARMY NEEDS YOU

but who needs USA Army?"10

${ }^{9}$ Ferro, op. cit.

${ }^{10}$ Império, c. 1966. op.cit.
Para Império, ${ }^{11}$ a Pop parte da constatação que o mundo está em crise; que os conflitos - a guerra - são produtos do capitalismo afoito na manutenção do tipo de vida da classe média, da "sociedade de consumo que gerou: os Estados Unidos". A linguagem responde a essa constatação de forma objetiva direta, desviando-se das elaborações que chama de informalismo e tachismo, mas continua sendo parte indissociável do sistema que a gerou.

A Pop é descrita por ele como "produto da classe média consumidora" que assume a imagem dos próprios objetos de consumo, substituindo a história da arte por artigos da indústria de massas. Nesse processo, divorcia-se da pintura para ligarse à linguagem publicidade, alimentando-se dela. Sérgio Ferro aprofunda essa análise:

A 'pop' é produto também da consciência da violência. Mas, de uma consciência culpada, com uma culpa vaga. Sua culpa é ser parte da massa amorfa que consente o poder político, militar e econômico concentrado responsável por uma violência no mundo inteiro - no Congo, na Grécia, no Laos, no Vietnã, no Brasil e, mesmo, no Harlem. E o empenho maior desta massa é esconder, de si própria, esta evidência: seu reconhecimento implicaria na escolha pesada entre compactuar ou resistir."12

Mas a apropriação que esse artistas fazem da Pop em suas pinturas têm algumas características importantes que dão tom da operação a que buscam submeter essa linguagem estadounidense para mostrar que o "rei está nu", como diz Império. Trata-se de fazer comparecer os traços de uma economia subdesenvolvida, de industrialização precária e um sistema de produção violento.

"Depois, por distorções e radicalizações, tentamos enxertar alguma coisa nestas importações. E, mesmo assim, exprimimos aquilo que somos, porque somos o que de nós conseguimos fazer dentro dos limites e padrões que as metrópoles nos impõe. Poderá vir dia diferente, mas ainda não veio."13

Assim a Pintura Nova é mais grossa, segundo Ferro, ao contrário da sofisticação lisa e uniforme de trabalhos como os de Andy Warhol e Rosenquist. Faz comparecer a fatura artesanal do quadro como um dado, indicativo de uma presença, a

\footnotetext{
${ }^{11}$ Idem.

${ }^{12}$ Ferro, op.cit.

${ }^{13}$ Idem.
} 
mão de quem o fez. Na Marchadeira encontramos isso no aspecto matérico que cada camada de cor assume e nas marcas dos gestos empenhados em espalhala sobre a superfície da madeira. As características desse suporte, que indicam ser um objeto reutilizado, pois foi claramente produzido para outra função que não a de receber a pintura, e os vários objetos acoplados ao quadro, também carregam consigo os significados de uma economia precária que, com criatividade, sabe prolongar a vida útil daquilo que tem, aproveitando-se do pouco para outros usos. Flávio Império recorre a este expediente em sua pintura; fazendo do resíduo da cidade parte de sua pintura.

Outra característica importante da subversão da linguagem Pop é a caricatura e o seu potencial crítico. Ainda nas palavras de Ferro:

"Fez, inclusive, reaparecer a caricatura, própria do 'dada' e desprezada pela 'pop'. Própria de quem critica sobre opressão, não cabe na má-fé. É dizer, e fazer entender, o que não se diz, e a 'pop' não quer dizer o que, apesar dela mesma, diz. Aqui, a violência impede a denúncia da violência, lá, há que iludir a consciência da violência"14

Na Marchadeira este recurso já está anunciado no aspecto genérico - pouco subjetivo - e exagerado das feições da personagem. Também é presente no título, expresso pelo neologismo que dá à ligação desta senhora com a marcha conservadora contornos de uma prática recorrente; como se comparecer a protestos reacionários fosse seu meio de vida, tal como a fofoca é das fofoqueiras. Quem vê o quadro reconhece a distorção e o exagero na referência a essas senhoras que frequentavam o noticiário cotidiano do país como apoiadoras do Golpe Civil-Militar. Dessa forma o artista partilha com seu público o riso e o escárnio por meio da imagem ridícula que elabora de uma personagem que todos conhecem. ${ }^{15} \mathrm{Com}$ a caricatura, Império consegue apontar a opressão que impede a denúncia da violência, da qual o regime antidemocrático que governava o Brasil na época era a expressão. O crítico Mário Schemberg comenta esse ponto:

"Flávio Império ocupa uma posição especial no grupo dos cinco arquitetos pintores pelo seu temperamento satírico e sua preocupação política. Ele é indubitavelmente o Daumier da arte brasileira satírica de hoje, potencialmente um dos

${ }^{14}$ Idem.

${ }^{15}$ Para uma discussão mais detida sobre a caricatura, cf. Belluzzo, 1980. maiores pintores satíricos de todo o mundo.

[...]

Dotado de uma inteligência aguda e implacável, Flávio revela a desumanidade, a confusão e a inépcia vociferante dos reacionários brasileiros, desmascarando a sua vacuidade empolada [...]. Flávio desmascara e fustiga, sem se apiedar. Tem a maior eficácia política." 16

O próprio jeito como Flávio Império se apropria da Pop lhe impondo a fatura do subdesenvolvimento monta uma imagem caricata da linguagem estadunidense. A incorporação dos vários objetos - da quinquilharia - também formula o ridículo da Marchadeira: é um perfil que alude a um certo heroísmo, mas que é elaborado com - e tem como atributo - brinquedos de criança, fragmentos de um capitalismo subdesenvolvido e enferrujado; 0 atraso.

Posto dessa maneira, o potencial crítico da caricatura está atrelado à forma como esses fragmentos colaboram para a montagem da Marchadeira. Para isso, é importante nota-los como elementos extra-pintura que comparecem ali ora como imagens de si mesmos - coisas do mundo - ora como atributos daquela personagem. É o reconhecimento desse duplo aspecto que enseja a crítica por meio do ridículo e do caricato. Ferro localiza esse procedimento que é apropriado da Pop:

'De fato, imitando o 'dada', a 'pop' deu novo impulso para uma pintura atuante e politizada. Exemplo a técnica da 'desconstelação', procedimento essencial do 'dada' que é a retirada de alguma coisa ou fato de seu contexto normal e sua colocação em outro diferente. Com esta técnica é possível evidenciar aspectos ou significações habitualmente desprezados ou não percebidos."17

A presença desses objetos também faz parte da grossura da pintura, acusando seu contexto de produção, e o subdesenvolvimento do país. Como apontado, essa operação concorre para a construção da caricatura do reacionarismo. Ao reunir esses fragmentos Flávio Império chama atenção para seu aspecto ordinário, próprio de um resíduo gerado pelo cotidiano capitalista e, portanto, para uma realidade compartilhada por todos. Isso é apontado pelo crítico Flávio Motta quando comenta os relevos parte desse conjunto de trabalhos:

${ }^{16} \mathrm{O}$ título do texto é Cinco arquitetos pintores e foi publicado originalmente na revista Acrópole, 1965. O texto foi republicado com a data errada em coletânea Pensando a arte, cf, 1988:187-189.

${ }^{17}$ Ferro, op. cit. 
"O artista captou fragmentos da realidade. Estava parado na calçada. Olhava o chão enquanto esperava o sinal para atravessar. E viu, no asfalto, uma multidão de migalhas metálicas absolutamente amassadas [...]. Daí veio a sugestão sensacional, pegar todas essas coisas do chão e colocá-las no muro. Assim, tudo aquilo que se passa por cima, indiferente, emerge na condição de frontalidade como algo intransponível. $E$ faz pensar nas coisas que estão além, inclusive no pensamento que pensa em restabelecer ligações, nos recursos da lucidez capaz de estar presente no futuro mais distante e no passado mais envelhecido; nessa presença de tudo e todos no mesmo instante." 18

Ai está a pintura como instrumento de conhecimento da realidade como postulava Lefévre em seu texto. É assim porque aprofunda a experiência do cotidiano. Cada procedimento é usado na elaboração de um sistema móvel em que eles são apresentados em seu potencial crítico inerente, convocando o público para análise. Sobre esse sistema, falaremos adiante. Antes, cabe ressaltar seu aspecto de denúncia apontado por Sérgio Ferro; a Pintura Nova Brasileira é "anti", segundo ele; uma forma de reagir à "frustração generalizada a partir de 64, as restrições a qualquer ação livre e responsável, o irracionalismo mórbido que governa por procuração". ${ }^{19}$ De acordo com Ferro é uma arma, ainda que fraca. Nas palavras de Império:

"Muita gente acha minha pintura agressiva. Será? nos tempos que correm qualquer notícia de jornal é muito mais. Ou se lê muito pouco, ou existe uma crise generalizada de hipersensibilidade..."20

\section{Sistema móvel; o neutro e o máximo teatral.}

Se a pintura se pretende um instrumento de conhecimento da realidade, ela deve ser um sistema móvel. Segundo Flávio Império, em sua contribuição às Notas sobre arquitetura é essa a forma que permite a aprendizagem.

"Há quem se sinta profundamente moderno ao afirmar que o nosso século é 'caótico' e que o mundo do nosso tempo é 'nonsense'.

Essa atitude subjetivista resguarda o sossego da neutralidade incentivando o conforto heróico masoquista dos dramas pessoais.

${ }^{18}$ Texto inacabado de Flávio Motta, Os Metamoldes de Império, provavelmente escrito entre 1965-1967. Hoje no IEB-USP.

${ }^{19}$ Ferro, op.cit.

${ }^{20}$ Império, op. cit.
As relações humanas nunca foram cartesianas, a não ser em épocas cujos limites são oficialmente definidos. Para isso é necessário que se empregue a força, uma vez que o objetivo é reter a história.

O 'caótico' nasce de uma comparação simplista entre a aparência dos fatos ou duma ânsia idealista de significações finais para a 'explicação' do Universo.

Os sistemas não finalistas e móveis permitem conhecimento. Conhecimento como forma de participação e não como explicação definitiva, instrumento de verificação e não 'a verdade'."21

No trecho acima Império contrapõe dois sistemas, duas formas de apreensão da realidade. A primeira é aquela que busca organiza-la logicamente e, por não conseguir, conclui que ela é caótica. O objetivo dessa abordagem seria encontrar a verdade - ou até impor uma verdade. Possui a característica do unívoco, portanto, autoritário.

Já os sistemas móveis não têm uma finalidade unívoca, nem se movimentam em torno da verdade. São, em oposição, instrumentos de verificação da realidade. Aqui os sujeitos aprendem ao se depararem com uma situação e se darem conta de sua complexidade, percebendo as diversas forças que concorrem em sua construção. Por isso, os sistemas móveis convocam a participação do público por abrir a possibilidade de sínteses diversas.

Essa formulação tem semelhanças interessantes com as propostas de Berthold Brecht para um Teatro Épico. Em suas peças, o autor apresenta o público situações como resultado de forças sociais, e a quem vê, e não às personagens, é dado o poder da síntese. Segundo Augusto Boal:

"A poética de Brecht é a Poética da Conscientização: o mundo se revela transformável e a transformação começa no teatro mesmo, pois o espectador já não delega poderes ao personagem para que pense em seu lugar $[\ldots .]^{\prime 22}$

Imprescindível dizer que Augusto Boal e Flávio Império trabalham juntos desde 1957, quando o artista se aproxima do Teatro de Arena. O estudo da obra de Bertold Brecht ${ }^{23}$ e montagens de suas peças - por exemplo Os Fuzis da Mãe Carrar

${ }^{21}$ Mesma reunião de textos escritos pelos três arquitetos já citada. Cf. Ferro, 2006.

22 Trecho do texto Conceito do "Épico" de Augusto Boal, escrito em Buenos Aires em 1973. Cf. Boal, 2005, p. 236 .

${ }^{23}$ Sobre Brecht no Brasil ver Encenações Brasileiras - Brecht: Monstro Sagrado? de 1967, originalmente publicado no Suplemento Literário d'O Estado de São Paulo. Cf. Rosenfeld, 2012, pp. 93-100. 
(1962) - permeiam não só a trajetória da companhia, como a de Império. ${ }^{24}$ Por isso, tal como seu trabalho com Sérgio Ferro e Rodrigo Lefévre em arquitetura, podemos ver o quanto suas reflexões no teatro alimentam a pintura que faz.

Sua pintura parece ensejar algo muito parecido com aquilo que Brecht queria do público, que Boal define como Poética da Conscientização. Como sistema móvel se aproxima do que o autor alemão chama de de Versuche, ensaio, ou experimentos sociológicos nos quais o público é convocado a fazer a síntese daquilo que vê. ${ }^{25}$ Não entra na história, mas se vê frente a ela. Em vez de envolver-se, estuda. O ator não atua, e sim narra, colocando quem vê na posição de observador. Ao contrário de entreter, esvaziando a potência da audiência, desperta-lhe a ação. Por isso, não trabalha sobre a emoção como a forma dramática do teatro, partiIhando experiências, mas força a decisão. No lugar dos sentimentos subjetivos da personagem, a atuação apresenta argumentos, e as forças sociais que determinam o contexto que a cena elabora. ${ }^{26}$ Como Anatol Rosenfeld resume a intenção é de:

"[...] apresentar um "palco científico" capaz de esclarecer o público sobre a sociedade e a necessidade de transforma-la; capaz ao mesmo tempo de ativar o público, de nele suscitar a ação transformadora."27

Assim como uma personagem de Brecht, $A$ Marchadeira não é um retrato heróico ou uma alegoria negativa da senhora conservadora. Mas um esquema onde quem vê é colocado diante dos vários procedimentos - forças - que comparecem em sua elaboração. Não há possibilidade de identificação com o tema da pintura, mas de reconhecimento das ações que a formulam. Não se trata da representação da personagem ou da figuração de seus propósitos, mas da montagem da Marchadeira como resultado de várias operações significativas.

${ }^{24}$ Sobre isso ver texto de Iná Camargo Costa, publicado no catálogo da exposição retrospectiva do artista, Flávio Império em Cena, cf. Costa, 1997.

${ }^{25}$ Sobre o termo ver posfácio intitulado Brecht e a Teoria Teatral escrito por Anatol Rosenfeld em 1962 para a tradução brasileira de Cruzada de Crianças, de Berthold Brecht, publicada pela editora Brasiliense. O texto foi republicado em coletânea editada pela Perspectiva, ver Rosenfeld, 2012 p. 81.

${ }^{26}$ Este é um breve resumo da famosa comparação em que Brecht opõe a forma dramática do teatro vs. à forma épica do teatro, originalmente escrita como notas para as para a Ópera dos três vinténs (1928) e Ascensão e Queda da Cidade de Mahoganny (1928-1929). Cf. Rosenfeld, 1965, pintens $149-150$.

${ }^{27}$ Rosenfeld, 1965, p.148.
Essa não-identificação é própria do teatro de Brecht, para quem "Distanciar é ver em termos históricos." 28 Segundo ele, é somente a partir do estranhamento que o público é levado a estudar a cena com atenção, sem se perder em dramas individuais. Conforme Rosenfeld sobre Brecht:

"Para os filhos de uma época científica, eminentemente produtiva como a nossa, não pode existir divertimento mais produtivo que tomar uma atitude crítica em face das crônicas que narram as vicissitudes do convívio social. Esse alegre efeito didático é suscitado por toda estrutura épica da peça e principalmente pelo 'efeito de distanciamento' (Verfrem-dungseffekt = efeito de estranheza, alienação), mercê do qual o espectador começando a estranhar tantas coisas que pelo hábito se lhe afiguram familiares e por isso naturais e imutáveis, se convence da necessidade da intervenção transformadora"

A síntese é a ação a qual Império convoca o público por meio das várias operações que elaboram o quadro da Marchadeira e que causam estranhamento, pois sempre apresentam um deslocamento em relação à sua função original, chamando atenção de quem vê para seus significados: a apropriação da Pop, como linguagem do capitalismo, transformada pela técnica ${ }^{29}$ do subdesenvolvimento; o recurso à caricatura em que o público partilha o riso com o artista e não a identificação com a personagem; e, por fim, a incorporação de elementos extra-pintura que se mostram estranhos àquele contexto e, por isso, chamam atenção sobre seu contexto de produção.

Ao estranhamento causado pela caricatura de Flávio Império, podemos relacionar com o que Rosenfeld diz sobre o cômico em Brecht:

"A combinação entre o elemento cômico e o didático resulta em sátira. Entre os recursos satíricos usados encontra-se também o grotesco [...]. Não é preciso dizer que a própria essência do grotesco é tornar 'tornar estranho' pela associação incoerente, pela conjugação do díspar, pela fusão do que não se casa [...] Brecht, porém, usa recursos grotescos e torna o mundo desfamiliar a fim de explicar e orientar." 30

\footnotetext{
${ }^{28}$ Brecht apud Rosenfeld, 1965, p. 155.

${ }^{29}$ O subdesenvolvimento visto como técnica está em Ferro, op. cit.

${ }^{30}$ Rosenfeld, op.cit., p.158.
} 
A associação incoerente também aparece na incorporação de pequenos objetos ao quadro. Estes elementos extra-pintura ${ }^{31}$ são usados com intenção de provocar o estranhamento e, com isso, fazer o público se perguntar o que são e o que eles substituem na forma de atributos; os significados de sua utilização; e como esses significados reiteram a caricatura da Marchadeira. No programa da peça Melhor Juiz, o Rei (1963), do Teatro de Arena, Flávio Império escreve o texto Uma boa experiência, no qual fala sobre os estatutos que cada elemento de sua cenografia assume na cena:

"O teatro realista [...] tem suas raízes na simulação do cognoscível inscrevendose na órbita das linguagens naturalistas. [...] é sempre dos objetos reais que parte e por meio deles que se comunica. Esses objetos mais particularizados ou mais generalizados, ganham um cunho mais próximo ou mais distante da natureza. No conjunto o conceito não chega a se inverter. [...]

Dentro do realismo teatral o emprego de um dos aspectos da realidade como fundamental é restritivo. Daí, o psicologismo ou a mera situação relativa dos objetos, ser restritiva como unidade cenográfica.

A forma colorida, o objeto atribuído, passou a ser pensado como nova entidade. Necessário se fazia precisar seu âmbito.

Voltando à antiga unidade aproximação-distanciamento, aplicada ao realismo teatral, entendemos o 'neutro' como o mínimo desgaste, menor obstáculo ao objeto, a identidade objeto-platéia. O máximo teatral, por conseguinte, como a estrutura abstrata da contradição das atribuições usuais.

Uma mesma cadeira, dentro de uma sala e embaixo de uma ponte empresta aos dois todos sentidos diferentes. Uma cadeira usual numa sala usual pode ser tida como 'neutra'. Se embaixo de uma ponte pode ser tida como 'máximo contraste'. Esses atributos surgem do sentido de usual para uma dada sociedade. Donde a unidade cenográfica depender a interrelação platéia-objeto cênico, como fator cultural.

Da relatividade dessas possibilidades surgem os graus do 'teatral' da imagem cênica.

O processo não é nunca de soma, mas de síntese."32

${ }^{31}$ A noção de extra-pintura está aqui no mesmo sentido que em Boal quando o autor fala do Teatro Épico de Erwin Piscator e o relaciona com Brecht. Naquele caso, trata-se da incorporação de recursos audiovisuais, como o cinema e slide, para situar ao publico a realidade histórica da qual recursos audiovisuais, como o cinema e slide,
se quer tratar na peça. Cf. Boal, op.cit., p.140.

${ }^{3}$ Império, Flávio. Uma Boa Experiência. Programa da peça O Melhor Juiz, O Rei. Teatro de Arena de São Paulo, 1963. Hoje parte do acervo do IEB-USP.
A síntese na cenografia de Império, portanto, é realizada no trânsito do público na relativização - entre o neutro e o máximo teatral de cada elemento. Ora, na Marchadeira também verificamos o mesmo processo. O já referido duplo-aspecto dos objetos que estão acoplados à pintura. Enquanto neutros eles são lixo, sucata, quinquilharia - testemunhas da própria obsolescência, resíduos do capitalismo. Coisas do cotidiano que, se não tivessem no quadro, nem notaríamos. Na posição neutra, eles apresentam a forma brasileira da Pop, impregnada do contexto local.

Assumem o máximo teatral quando são vistos como atributos da Marchadeira. Não é possível ignorar o que são, daí o estranhamento causado pela contradição entre o que são e a aparência que assumem no quadro. Neutro e máximo podem ser entendidos como forças que tensionam a Marchadeira entre o as coisas e suas atribuições; o cotidiano e sua narrativa; o subdesenvolvimento e o conservadorismo; o real e seus significados.

Nos anos que se seguiram à redemocratização do Brasil, $A$ Marchadeira das famílias bem pensantes, bem como outras obras de Flávio Império da época, integraram algumas exposições retrospectivas, onde foram expostas junto a trabalhos de outros artistas da década de 1960. Se tornou comum relacionar a produção desses artistas em grandes grupos que se movimentavam em torno das noções de volta a figuração, novo realismo, arte pop brasileira ${ }^{33}$, entre outros, e atrela-la à resistência cultural ao regime militar e autoritário.

Assim, transcorridos anos de normalidade democrática, muitos dos sentidos que essas obras partilhavam com o público se perdem. O cotidiano não é mais o mesmo. $E$ as referências que cada trabalho faz uma realidade imediata perdem lugar para classificações mais amplas cujo objetivo é a compreensão do que passou. Essas classificações impõe certa rigidez ao sistema móvel da Marchadeira pois já oferecem ao público uma conclusão mais estruturada - na qual a síntese das muitas operações resulta em uma representação da ação de um artista contra o período de exceção.

Mas essa visão também é parte do passado. Desde 2013, de maneira mais intensa durante o impeachment da presidenta Dilma Roussef (2016), e após 2018 com Jair Bolsonaro, o reacionarismo voltou a ganhar força no Brasil, impingindo-nos

${ }^{33}$ Sobre essas várias noções, ver Peccinini, 1999. 
pautas absurdas. A Marchadeira das famílias bem pensantes volta a ser uma imagem que frequenta nosso cotidiano, e a nos aterrorizar. Com este impulso urgente da atualidade voltamos a partilhar da complexidade de seus significados com mais facilidade e o sistema do quadro recupera sua mobilidade, nos convocando a operar a síntese, e promover a ação.

\section{Referências}

BELLUZZO, Ana Maria. Voltolino e as raízes do modernismo. Dissertação de mestrado. São Paulo: Escola de Comunicação e Artes (ECA-USP), 1980.

BOAL, Augusto. Teatro do Oprimido e outras poéticas políticas. Rio de Janeiro: Editora Civilização Brasileira, 2005.

COSTA, Iná Camargo. Um enredo para Flávio Império. In: Flávio Império/ Renina Katz e Amélia Hamburger (org.). São Paulo: Edusp, 1999.

FERRO, Sérgio. Os limites da denúncia. In: Rex Time. São Paulo: março/1967.

. Arquitetura e Trabalho livre. São Paulo: Cosac Naify, 2006.

IMPÉRIO, Flávio. Uma Boa Experiência. O Melhor Juiz, O Reil programa da peça. Teatro de Arena de São Paulo, 1963. Disponível em: Flávio Império (website), www.flavioimperio.com.br. (último acesso: 02/07/2020).

A pintura nova tem a cara do cotidiano. Documento datilografado e não publicado, c. 1966. Disponível em: Flávio Império (website), www.flavioimperio.com.br. (último acesso: 02/07/2020).

PECCININI, Daisy. Figurações: Brasil anos 60. São Paulo: Edusp e Instituto Itaú Cultural, 1999.

QUEVEDO, Yuri Fomin. Entre Marchadeiras, Mãos e Mangarás: Flávio Império e as Artes Plásticas. Dissertação de mestrado. Universidade de São Paulo: Faculdade de Arquitetura e Urbanismo, 2019.

ROSENFELD, Anatol. O Teatro Épico. São Paulo: Editora Buriti, 1965.
. Brecht e o Teatro Épico. São Paulo: Perspectiva, 2012.

SESTINI, Dharana. A "mulher brasileira” em ação: motivações e imperativos para o golpe militar de 1964. Dissertação de mestrado. Universidade de São Paulo: Faculdade de Filosofia, Letras e Ciências Humanas, 2008

SCHEMBERG, Mário. Cinco arquitetos pintores. In: Pensando a arte. São Paulo: Nova Stella, 1988, pp. 187-189. 